\title{
Symbolizm złotego pasa Chrystusa zmartwychwstałego (Ap 1,13) w świetle literatury greckiej
}

\author{
The Symbolism of Risen Christ's Golden Sash (Rev 1:13) \\ in the Light of Greek Literature
}

\author{
PAWE PODESZWA \\ Uniwersytet im. Adama Mickiewicza w Poznaniu \\ podpaw@amu.edu.pl, ORCID: 0000-0002-4000-1660
}

\begin{abstract}
Streszczenie: Artykuł podejmuje zagadnienie symbolicznego znaczenia złotego pasa Jezusa (Ap 1,13) w inauguracyjnej wizji Apokalipsy (1,12-20). Źródłem tego symbolizmu chromatycznego jest najpierw Stary Testament, w którego świetle złoty kolor wskazuje na Jezusa jako Boga, Króla i Arcykapłana. W zaproponowanej refleksji poszukuje się także możliwych źródeł (inspiracji) w antycznej literaturze greckiej, zwłaszcza w opisach bóstw mitologicznych: Zeusa, Posejdona, Artemidy, Apollona, Kirke. Analiza wybranych fragmentów, zaczerpniętych z lliady i Odysei Homera oraz Hymnów Kallimacha, pozwala stwierdzić, że złoto jest ich dominującym kolorem, a wiele elementów stroju, ekwipunku i sprzętów, którymi posługują się greccy bogowie, zostało wykonanych z tego szlachetnego i cennego materiału. Można zatem powiedzieć, że barwa złota jest „kolorem bogów”, a sam kruszec kojarzy się w sposób naturalny w bóstwem. Autor Apokalipsy mógł zatem wykorzystać obrazy i motywy zapożyczone z mitologii i symboliki greckiej, traktując je jako materiał literacki, wyrażający symbolicznie prawdę o transcendencji Jezusa.
\end{abstract}

Słowa kluczowe: Apokalipsa, złoty pas Jezusa, złoto, symbolizm, transcendencja, królewskość, kapłaństwo, mitologia grecka

\begin{abstract}
The article deals with the symbolic meaning of Jesus' golden sash (Rev 1:13) in the inaugural vision of Revelation (1:12-20). The source of this chromatic symbolism is first found in The Old Testament, in the light of which gold color points at Jesus as God, King, and High Priest. In the proposed reflection, the author looks for the possible source (of inspiration) in ancient Greek literature, especially in mythological depictions of divinities: Zeus, Poseidon, Artemis, Apollo, and Circe. The analysis of chosen fragments, cited from Homer's lliad and Odyssey and Challimachus' Hymns, enable us to ascertain that gold is the dominant color and that many elements of garment, inventory, and equipment used by Greek divinities are made from this valuable material. It becomes clear that gold or gold ore is naturally associated with diety and is the "color of gods." The author of Revelation could use images and motives borrowed from Greek imagery and mythology, treating them as literary material which symbolically expresses the truth about Jesus' transcendence.
\end{abstract}

Keywords: Revelation, Jesus' golden sash, gold, symbolism, transcendence, royalty, priesthood, Greek mythology 
Znane jest twierdzenie kard. Gianfranco Ravasiego, że „symbolizm jest jakby płaszczem, który rozciąga się nad wszystkimi stronicami Apokalipsy"1. Nawet pobieżna lektura ostatniej księgi Nowego Testamentu pozwala zauważyć czytelnikowi, iż „mamy do czynienia z prawdziwym arsenałem obrazów, porównań, znaków, symboli, metafor, które często bywają zaczerpnięte z Biblii”2. W ten sposób symbol, rozumiany jako znak, przenoszący ,intelekt odbiorcy z poziomu materialnego i dosłownego na poziom abstrakcyjny i transcendentny"3, staje się uprzywilejowanym narzędziem apokaliptycznej komunikacji ${ }^{4}$. Aby zatem odkryć zamierzone przez autora przesłanie Apokalipsy, trzeba próbować „odsłonić symbole” i dotrzeć do ukrytych za nimi rzeczywistości ${ }^{5}$.

Dariusz Kotecki sformułował kilka zasad, które powinny zostać uwzględnione przy analizie symbolizmu Apokalipsy: 1) zauważyć ciągłą budowę symboli (to znaczy taką, która sprzyja figuratywnemu odwzorowaniu obrazu) lub przerwaną (to znaczy taką, która nie pozwala nam sobie wyobrazić obrazu; stąd każdy z symbolicznych elementów tworzących całość obrazu musi być interpretowany oddzielnie i dopiero złożona razem mozaika interpretacji daje jakieś sensowne wytłumaczenie obrazu);2) wziąć pod uwagę skomplikowany i niekiedy trudny do odtworzenia proces powstawania symbolu; 3) uwzględnić „metamorfozę symboli”: często konfiguracja symbolu nie jest rzeczą stałą, ale ulega pewnej transformacji, dotyczącej jakiegoś wybranego elementu lub całości; 4) mieć na uwadze możliwe źródła symboliki Apokalipsy: Stary Testament, judaizm (przede wszystkim apokaliptyka żydowska), Nowy Testament oraz świat grecko-rzymski; 5) spojrzeć na sposób komunikacji treści symbolicznych (Apokalipsa zaprasza słuchacza-czytelnika do współuczestnictwa w spotkaniu z niezwykłą treścią); 6) uwzględnić kategorie (rodzaje) symboli: kosmiczny, antropologiczny, teriomorficzny, chromatyczny oraz arytmetyczny ${ }^{6}$.

Jak wynika $z$ wyżej wymienionych kryteriów poprawnej interpretacji symbolizmu Apokalipsy, ważną rolę odgrywa uwzględnienie i próba określenia źródła lub źródeł symboli ${ }^{7}$. Prawdą jest, że dla większości z nich podstawowymi źródłami

\footnotetext{
Ravasi, Apokalipsa, 9.

Ravasi, Apokalipsa, 9.

Kiejza, „Charakter”, 23.

Zob. Rojas Gálvez, I simboli, 105.

Zob. Marconi, Le mille.

Zob. Kotecki, „Kryteria”, 28-30; zob. także Kotecki, Jezus, 22-23; Marek Karczewski (Reinterpretacja, 50-70) zaproponował następujące kategorie symboli: kosmiczny (to wszystkie obrazy dotyczące różnych sektorów stworzonego świata: niebo, ziemia, słońce, księżyc, gwiazdy; kataklizmy kosmiczne: słońce, które traci swój blask, księżyc stający się krwią, gwiazdy spadające z nieba), antropologiczny (to wszystko, co dotyczy człowieka i jego świata: wygląd, ubiór, postawy, zachowanie, środowisko, sytuacje życiowe itp.), teriomorficzny (dotyczy symboliki opisanej za pomocą obrazów zwierząt: smok, szarańcza, bestie, lew, baranek), kolorów (można w Apokalipsie wyróżnić pięć kolorów głównych: biały, złoty, ognisto-szkarłatny, trupioblady i czarny) oraz liczb $(3 ; 3,5 ; 4 ; 7 ; 10 ; 12 ; 24 ; 666 ; 42 ; 1260 ; 144$ 000). Zob. także Vanni, L'Apocalisse, 34-55.

7 Zob. Beale, The Book, 58.
} 
są księgi biblijne Starego i Nowego Testamentu oraz żydowska literatura apokaliptyczna ${ }^{8}$, ale

w wizjach Apokalipsy znajdziemy także obrazy wzięte z mitologii, a w judaizmie nie poświadczone. Tak czy inaczej, księga zawiera elementy pokrewne względem pogańskich wyroczni, proroctw i znaków od bóstw. Miały one wpływ na sprawy życiowe, a także polityczne. Wyroczni bowiem oczekiwano. Z kolei wykorzystaniu motywów mitycznych sprzyjał ich charakter symboliczny. Służą one za materiał literacki, wywarły więc pewien wpływ, ale ich wykorzystanie jest podporządkowane koncepcji całości.

W niniejszym artykule chciałbym przywołać możliwe fragmenty literatury greckiej, które pozwalają na pełniejszą interpretację symboliki złotego pasa zmartwychwstałego Chrystusa w inauguracyjnej wizji Syna Człowieczego $(1,9-20)^{10}$, będącej wprowadzeniem do pierwszej części księgi - Listów do siedmiu Kościołów (2,1-3,22). W 1,13 czytamy, że wizjoner zobaczył „pośród świeczników kogoś podobnego do Syna Człowieczego, odzianego w szatę do stóp i przepasanego na piersiach złotym pasem". W wielu publikacjach słusznie zwraca się uwagę, że zarówno szata Syna Człowieczego, jak i złoty pas symbolicznie wskazują na Jego kapłaństwo i królewskość ${ }^{11}$. Złoty kolor w stroju jest „atrybutem królewskim i boskim” ${ }^{2}$, a liczne możliwe odniesienia do Starego Testamentu wydają się być oczywiste i będą stanowić konieczny punkt wyjścia dla symbolicznej interpretacji złotego pasa Chrystusa ${ }^{13}$. Pytamy jednak także o możliwe paralele w mitologicznej literaturze greckiej, które mogłyby być źródłem, a przynajmniej inspiracją ${ }^{14}$ dla symbolizmu złotego pasa Chrystusa jako elementu boskiego stroju, co jeszcze bardziej symbolicznie wyrażałoby i podkreślało Jego transcendencję $e^{15}$.

8 Zob. Wojciechowski, „Wpływy greckie w Apokalipsie”, 117.

9 Wojciechowski, Wplywy greckie w Biblii, 332-333.

10 Szczegółowe omówienie całej wizji zob. Kotecki, Jezus, 136-204; zob. także Podeszwa „Pan świeczników”, 64-75.

11 Podeszwa, „Chrystus”, 202-206.

12 Wojciechowski, Apokalipsa, 117.

13 Zob. Karczewski, Reinterpretacja, 64. Autor zwraca uwagę, że „jednym z niebezpieczeństw w interpretacji symboliki chromatycznej Ap może okazać się przewartościowanie wpływu hellenistycznej literatury mitologicznej, przy jednoczesnym pominięciu całego spektrum znaczeń starotestamentalnych".

$14 \mathrm{Na}$ temat klasyfikacji paralel między tekstami biblijnymi a greckimi oraz różnych poziomów wpływów greckich na teksty biblijne zob. Wojciechowski, Wptywy greckie w Biblii, 10-18.

15 Michał Wojciechowski (Wplywy greckie w Biblii, 334) widzi następujące wpływy greckie w wizji inauguracyjnej: „Wizja Chrystusa w Ap 1,12-20 nawiązuje do Syna Człowieczego z Dn 7,9.13; 10,5-6. Jednocześnie jej elementy pokrywają się z ikonografią Heliosa (blask, gwiazdy), którą zawłaszczali też cesarze. $\mathrm{Na}$ aureusie na cześć Domicji Longiny z 83/84 r. figuruje książę z siedmioma gwiazdami. W Ap 1,18 obraz kluczy w boskim ręku wydaje się pochodzenia greckiego. Pluton miał mieć klucze Hadesu (Pauzaniasz, Wędrówki po Helladzie 5,20,3); tak samo jeden z trzech podziemnych sędziów Ajakos (Apollodor z Aten, Biblioteka 3,12,6 i in.). Utożsamiana z różnymi boginiami Hekate miała klucze całego świata (Hymny orfickie 1,7 z II w.) i nosiła przydomek «klucznicy». Innym bóstwom też przypisywano 


\section{Zmartwychwstały Pan „pośród świeczników”}

Jan otrzymał wizję na wyspie Patmos $(1,9)$, którą ma spisać i przekazać siedmiu Kościołom Azji Mniejszej (1,11). Zmartwychwstały Pan ukazał się podczas litur-

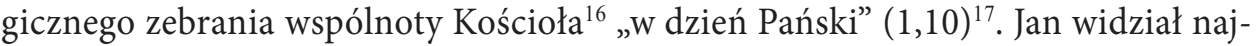
pierw „siedem złotych świeczników” $(1,12)$ i „kogoś podobnego do Syna Człowieczego" $(1,13)$. Intuicyjnie wiadomo, że chodzi o Chrystusa zmartwychwstałego, ale staje się to oczywiste dopiero w 1,17b-18, gdzie „ktoś podobny do Syna Człowieczego" sam przedstawia się w następujący sposób: „Ja jestem Pierwszy i Ostatni, i Żyjący, byłem umarły, a oto jestem Żyjący na wieki wieków i mam klucze Śmierci i Otchłani”.

Zmartwychwstały ukazał się „pośród świeczników” $(1,13)$. Chodzi o świeczniki ze szczerego złota, będące na wyposażeniu Przybytku (Wj 25,31) ${ }^{18}$. Tutaj po raz pierwszy pojawia się w Apokalipsie kolor złoty, który w księdze często związany „jest z liturgią i symbolizuje bliskość Bożej tajemnicy"19: złote świeczniki $(1,12.20 ; 2,1)$, złote wieńce Starców $(4,4)$; złote czasze pełne kadzideł $(5,8 ; 15,7)$, złota kadzielnica $(8,3)$, złoty ołtarz $(8,3 ; 9,13)$, złoty wieniec na głowie Siedzącego na obłoku $(14,14)$, złote pasy siedmiu aniołów $(15,6)^{20}$. Według wyjaśnienia w 1,20 „siedem świeczników to siedem Kościołów". Uwzględniając symbolizm arytmetyczny ${ }^{21}$ cyfry siedem,

rozmaite klucze. Wtórnie o boskich kluczach mówią teksty rabiniczne. Ap 1,20 i sąsiednie nawiązują do symboliki astralnej. Filon z Aleksandrii twierdzi wprost, że siedem lamp menory symbolizuje siedem ciał niebieskich (Kto jest dziedzicem boskich dóbr, 221-222). Klemens z Aleksandrii porównał lampy menory z jaśniejącymi planetami ze słońcem w centrum (Kobierce 5,6). Utożsamienie aniołów z gwiazdami ma za tło kosmologiczne poglądy starożytne, według których ciała niebieskie były boskie, albo też kierowały nimi niebiańskie inteligencje. Choć Biblia odrzuca astrologię i ubóstwianie ciał niebieskich, tu najwyraźniej nawiązano do skojarzeń potocznych. Zaznaczmy, że przyswojenie motywów astralnych i astrologicznych mogło się dokonać za pośrednictwem judaizmu ówczesnego, skoro są one obecne już w Księdze Daniela”. Jak zatem można zauważyć autor nie przywołuje żadnych możliwych paralel dla złotego pasa Chrystusa. Natomiast Dariusz Kotecki (Jezus, 146) pisze: „Odniesienia do złota służyły także w poezji greckiej do opisu bóstw”, i odsyła w przypisie 65 do komentarza Davida E. Aune’a (Revelation, 94). Na temat pozostałych wpływów greckich w Apokalipsie, zob. Wojciechowski, Wptywy greckie w Biblii, 332-340.

16 Zob. Manunza, L'Apocalisse.

17 Zob. Lijka, „Dzień Pański”, 33-39.

18 Ponieważ złoto było rzadkim i cennym surowcem, wykorzystywano je do wyrabiania przedmiotów o szczególnym przeznaczeniu, a zwłaszcza sprzęty do świątyni, takie jak Arka Przymierza, dwa cheruby umieszczone na jej pokrywie (przebłagalnia), menora oraz złoty ołtarz dla chlebów pokładnych, czyli obecności (Wj 25-26; 28; 30-31). Według $1 \mathrm{Krl}$ 7,48-50 Salomon sporządził następujące przedmioty dla świątyni jerozolimskiej: „złoty ołtarz, złoty stół na chleby pokładne, pięć świeczników ze szczerego złota przed sanktuarium po prawej i pięć po lewej stronie, kwiaty, lampy, szczypce ze złota, czarki, nożyce do oczyszczania lamp, kropielnice, czasze i popielnice ze szczerego złota, a także złote zawiasy przy drzwiach do wewnętrznej komnaty sanktuarium i przy drzwiach głównej budowli”.

19 Rojas Gálvez, I simboli, 126.

20 Zob. Popielewski, Alleluja!, 113.

21 Zob. Biguzzi, „I numeri”, 143-166; Corsini, „I numeri”, 391-416; Díez Merino, „La numerología”, 59-98; Zbroja, „Symbolika”, 131-158. 
która wyraża pełnię, oraz symbolizm świeczników, chodzi o wspólnotę Kościoła widzianą w swej pełni, która gromadzi się na liturgii i w ten sposób wchodzi w kontakt z transcendencją. Świeczniki wyznaczają zatem idealną przestrzeń (Kościół i liturgię) obecności i aktywności zmartwychwstałego Pana ${ }^{22}$.

\section{Szata Zmartwychwstałego}

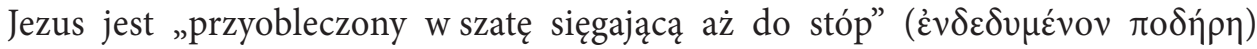
$(1,13)$. Wizja początkowa odsyła czytelnika do proroctwa Dn 10,5, gdzie czytamy, że Daniel zobaczył „kogoś ubranego w lnianą szatę” ( $\dot{v} v \delta \varepsilon \delta v \mu \varepsilon ́ v o \varsigma ~ \beta u ́ \sigma \sigma ı v \alpha)$. Mimo że odwołanie się do Starego Testamentu jest oczywiste, autor Apokalipsy wprowa-

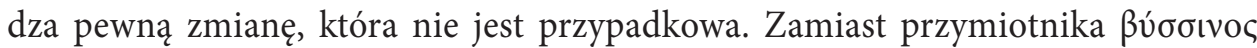

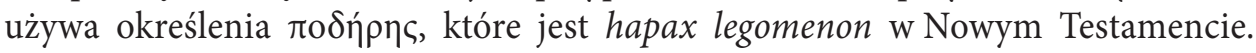
Oznacza ono „długą szatę sięgającą aż do stóp”. Rzeczownik ten jest natomiast obecny w LXX, gdzie na 12 razy aż 8 razy wprost oznacza szatę arcykapłana (Wj 25,7; $28,4.31 ; 29,5 ; 35,9 ; \mathrm{Za} 3,4 ; \mathrm{Mdr} 18,24 ;$ Syr 45,8 ${ }^{23}$. Według antropomorficznego symbolizmu Apokalipsy strój wyraża tożsamość osoby, która go nosi oraz jej relację do tego, który ją widzi. Szata nie jest symbolem czegoś zewnętrznego, ale wręcz stanu wewnętrznego, określonej postawy tego, kto ją nosi ${ }^{24}$. Mamy zatem pierwszą w Apokalipsie prezentację Chrystusa zmartwychwstałego - jako arcykapłana ${ }^{25}$, który zostaje przedstawiony w relacji kapłańskiej do wizjonera i wspólnoty Kościo$\mathfrak{~ ł a ~}^{26}$.Zmartwychwstały „Świadek Wierny, Pierworodny spośród umarłych i Władca królów ziemi” (1,5), uczynił chrześcijan „królestwem, kapłanami dla Boga, swego Ojca" $(1,6)^{27}$.

22 Zob. Vanni, L’Apocalisse, 125; także Kotecki, Duch Święty, 203.

23 Aune (Revelation, 93) wylicza pięć rzeczowników hebrajskich, które są tłumaczone w LXX przy pomo-

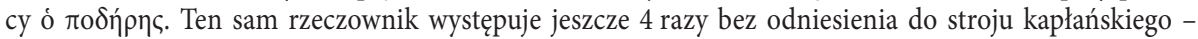
Ez 9,2.3.11 oraz Syr 27,8.

24 Zob. Gądecki, Wstęp, 173

25 Zob. Jankowski, Apokalipsa, 143; Corsini, Apocalisse, 136; Ostański, Objawienie, 81; Biguzzi, Apocalisse, 83-84; Jelonek, Biblijna teologia, 165-166; Szamot, Apokalipsa, 304; David H. Stern (Komentarz, 1059) interpretuje strój Jezusa jako „ubiór kohena hagadola”. Zdaniem Alberta Vanhoye’a („L’Apocalisse”, 263) nawiązanie do proroka Daniela jest argumentem przeciwko interpretacji szaty Jezusa zmartwychwstałego jako kapłańskiej, ponieważ w proroctwie Daniela nie chodzi o kapłana, ale o tajemniczą postać. Ponadto

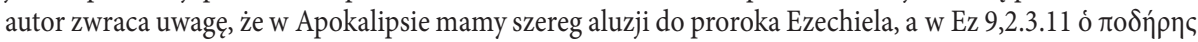
oznacza szatę pisarza, a nie kapłana.

26 Zob. Rigato, Giovanni, 316.

27 Zob. Podeszwa, Paschalna, 149-170, 193-197. 


\section{Złoty pas Chrystusa}

Kapłańską interpretację szaty Jezusa potwierdza jeszcze jeden element, który należy do opisanego stroju Syna Człowieczego, a mianowicie złoty pas (szarfa), którym jest

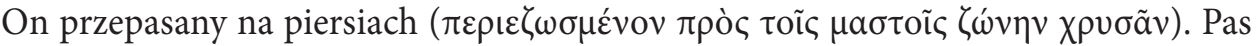
zasługuje na uwagę z dwóch powodów. Najpierw jest on złoty. Mamy także tutaj nawiązanie do wizji Daniela, który ujrzał „kogoś ubranego w lnianą szatę, a jego biodra były przepasane pasem z czystego złota ${ }^{28 ”}(10,5)$. Jak powiedzieliśmy wcześniej, jest to charakterystyczny kolor, który w Apokalipsie pojawia się często w kontekście li-

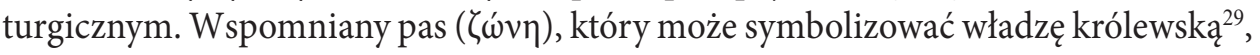
występuje także u Józefa Flawiusza w jego opisie stroju arcykapłańskiego: „Przepasuje ją [szatę] szarfa, która błyszczy takimi samymi barwami, jakie zdobią poprzednią szarfę, i jest przetykana złotem" ${ }^{30}$. Podobnie w Ap 15,6 czytamy o aniołach, którzy wyszli ze świątyni, że „byli ubrani w czysty, błyszczący len i przepasani na piersiach

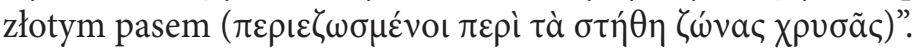

W odniesieniu do poprzednich tekstów mamy jeszcze jedną znaczącą zmia-

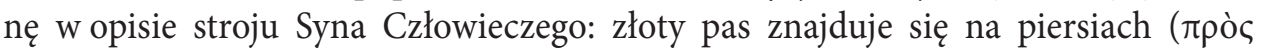

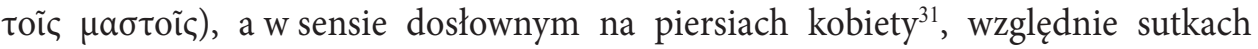

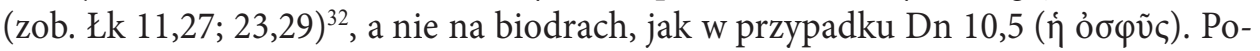
dobnie - porównując opis pasa Jezusa z Ap 15,6 - zauważymy, że aniołowie mają złote pasy na piersiach ( $\pi \varepsilon \rho \grave{~} \tau \grave{\alpha} \sigma \tau \eta \dot{\theta} \theta \eta$ ), ale użyty zostaje inny rzeczownik niż w opi-

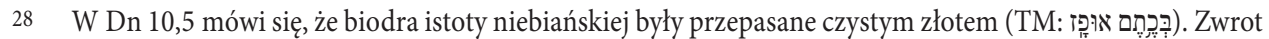
ten nie jest niejasny. Słowo כֶּ oznacza złoto (np. Hi 31,24; Prz 25,12), które często jest łączone z Ofirem w wyrażeniu „złoto Ofiru” (Iz 13,12; Ps 45,10; Hi 28,16). W Dn 10,5 mówiłoby się o „złocie z Ufaz”, jednak w całej Biblii, poza Jr 10,9, nie wspomina się nigdzie takiej miejscowości. Stąd nie jest wykluczo-

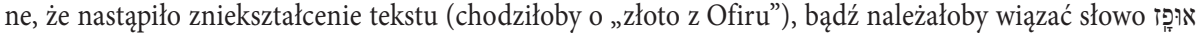

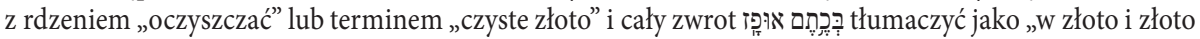
czyste", zob. Parchem, Księga, 629.

29 Gregory K. Beale (The Book, 209) zwraca uwagę, że mamy możliwą aluzję do pasa Eliakima, syna Chilkiasza (Iz 22,21). Proroctwo jednak nie mówi, że jest on złoty. Eliakim będzie miał „władzę kluczy” nad domem Dawida (Iz 22,22), motyw, który w Ap 3,7 został odniesiony do Chrystusa.

30 Józef Flawiusz, Dawne III,7,4 (Kubiak - Radożycki, 186).

31 Maria-Luisa Rigato (Giovanni, 317) zwraca uwagę na fakt użycia słowa, które odnosi się do piersi kobiety. Według autorki mamy tutaj odniesienie do Jezusa - Adama, którego Bóg stworzył „mężczyzną i kobietą” (Rdz 1,27). Chrystus jako nowy Adam jest określony jako „podobny do Syna Człowieczego”, które należałoby rozumieć jako „podobny do istoty ludzkiej”, na co wskazuje oryginalne aramejskie określenie kebar 'enosh, które zostało przełożone przez LXX: „jako syn człowieczy”. Paralelnie do rozumienia Pawłowego $(\mathrm{Ga} 3,28)$ jak „per l'Adam scompare il genere, resta la specie umana. Analogamente per il Cristo trascendente scompare la maschilità e resta l'umanità, ossia la natura umana e quella divina". Zob. także Aune, Revelation, 94, który zwraca uwagę na możliwą paralelę do przedstawień boga Mitry.

32 Zob. Wojciechowski, Apokalipsa, 117. Jednocześnie autor zwraca uwagę, że do mężczyzny słowo „piersi” ( $\mu \alpha \sigma \tau o i)$ odniesione jest tylko w greckiej wersji Pnp 1,2, gdzie chodzi o piersi oblubieńca. Być może, jeśli nie ma tutaj błędu w grece Apokalipsy, mamy tu skojarzenie z tym motywem i świadectwo alegorycznego odczytania Pieśni nad Pieśniami i odniesienia jej do boskiego oblubieńca. 
sie Syna Człowieczego ${ }^{33}$. Chodziłoby tutaj raczej o piersi jako część klatki piersiowej. W Ap 1,13 mamy zatem przemieszczenie złotego pasa w górę i określenie zarezerwowane tylko dla Jezusa, co podkreśla wyjątkową jakość kapłaństwa Jezusowego ${ }^{34}$, a także może być rozumiane jako alegoria wcielenia, bez którego nie byłoby możliwe dzieło odkupienia ${ }^{35}$.

Słusznie zauważa D. Kotecki, że

złoto należało przez wieki (pozostało tak także w myśleniu przeciętnego człowieka) do najcenniejszych metali, dlatego też służyło jako punkt odniesienia w porównaniach mających na celu podkreślenie wartości kogoś jedynego w swoim rodzaju, np. Boga: „Wszechmocny twą sztabą złota i srebrem błyszczącym dla ciebie" (Hi 22,25). Złoty pas może podkreślać także nieoszacowaną wartość całego ubioru. Ten, kto nosi taki ubiór musi być wyjątkowy, niepowtarzalny, jedyny w swoim rodzaju. Ta wyjątkowość dotyczyć może zarówno jego godności kapłańskiej, jak i królewskiej ${ }^{36}$.

Wspominane wiele razy w Biblii złoto było przede wszystkim symbolem bogactwa (Iz 2,7; 60,17), zwłaszcza królów i możnowładców (Rdz 41,42; 2 Krn 1,15; Est 4,11; 8,15). Abraham i Salomon zgromadzili wielkie ilości złota (Rdz 13,2; $1 \mathrm{Krl} 10,14-29)$, które było znakiem Bożego błogosławieństwa. Także ze złota zrobiona była korona ( $2 \mathrm{Sm} \mathrm{12,30;} 1 \mathrm{Krn}$ 20,2; Est 8,15; Ps 21,4; Za 6,11) oraz tron (1 Krl 10,18), będące symbolami władzy królewskiej (zob. także 1 Mch 10,88-8937).

Złoto jest też symbolem cennych darów, które składa się królowi: „Królowa Saby usłyszała o Salomonie i o tym, co uczynił dla imienia Pana. Przybyła zatem, aby wystawić go na próbę, zadając mu trudne pytania. Przybyła do Jerozolimy z wielkim i wspaniałym orszakiem, $\mathrm{z}$ wielbłądami, niosącymi wonności, ogromne ilości złota i drogocennych kamieni” (1 Krl 10,1-2). Także prorok Izajasz zapowiadał, że narody

33 Na temat zależności między opisem stroju Jezusa a aniołów w 15,6 zob. Corsini, Apocalisse, 136-137.

34 Zob. Vanni, L'Apocalisse, 127; także Kotecki, Duch Święty, 169; Mounce, Apocalisse, 76. Przeciwko interpretacji kapłańskiej szaty i pasa Jezusa zob. Prigent, L’Apocalypse, 103-104.

35 Zob. Corsini, Apocalisse, 137.

36 Kotecki, Jezus, 156. Warto także zwrócić uwagę, że pas często służył zabezpieczeniu miecza, stąd był także symbolem wojownika; zob. Aune, Revelation, 94. Autor przytacza fragment Eneidy Wergiliusza, opisujący herosa italskiego Turnusa, na którego ramieniu Eneasz zobaczył pas Pallasa, swojego towarzysza, zabitego wcześniej przez Turnusa:

Na Turnusowym ramieniu wysoko

Ujrzał nieszczęsny pas, błysnęły znane

Okucia. Pas to chłopięcy, Pallasa!

Turnus, co zranił go niegdyś i zabił,

Nosił na barkach tę oznakę wrogą (Vergilius, Eneida 12, 941-945 [Kubiak, 403]).

Warto zauważyć, że w wizji inauguracyjnej Chrystusa zmartwychwstałego też pojawia się miecz, który wychodzi z Jego ust $(1,16)$. Także sam motyw Jezusa-Wojownika nie jest obcy Apokalipsie $(5,5 ; 6,2$; 19,11-21).

37 W tekście jest mowa o złotej sprzączce, zob. Romaniuk - Jankowski, Kapłaństwo, 70. 
będą ciągnęły do Mesjasza, któremu „ofiarują złoto i kadzidło, nucąc radośnie hymny na cześć Pana" (Iz 60,6). Proroctwo to spełniło się, kiedy do Jezusa przybyli mędrcy ze Wschodu, „upadli na kolana, oddali Mu hołd. Otworzyli swe szkatuły i ofiarowali Mu dary: złoto, kadzidło i mirrę" (Mt 2,11). Złoto jest symbolem Jego królewskości, Boskiej władzy oraz panowania Chrystusa, jednoznacznie wskazując na Jezusa jako przynoszącego zbawienie Mesjasza - Króla, czyli najwyższego Pasterza Ludu Bożego.

Złoty pas Chrystusa zmartwychwstałego symbolizuje zatem Jego królewskość i kapłaństwo „na wzór Melchizedeka” (Hbr 5,6.10; 6,20; 7,11.15.17), „króla Szalemu, kapłana Boga Najwyższego" (Hbr 7,1) ${ }^{38}$. Ale kolor złoty, jak zostało to już zasygnalizowane, jest także symbolem samego Boga: „Wszechmocny twą sztabą złota i srebrem błyszczącym dla ciebie" (Hi 22,25), oraz kultu sprawowanego na Jego chwałę (wszystkie złote sprzęty świątynne), aby także w ten sposób „okazać cześć Najwyższemu tym, co najdrogocenniejsze na ziemi" ${ }^{39}$. W ten sposób kolor złoty staje się symbolem transcendencji Jezusa, co zostanie potwierdzone i rozwinięte przez dalsze elementy wizji: białe włosy, płomień ognia, rozżarzony metal i głos wielu wód, będące charakterystycznymi atrybutami Boga w teofaniach opisanych u Daniela i Ezechiela (Dn 9,9-10; Ez 1,4; 43,2) . $^{40}$

Dotychczasowe odniesienia do złotego pasa (szarfy) Jezusa zmartwychwstałego pochodziły ze Starego Testamentu. Jednak symbolika złota jako kruszcu i koloru „bożego", zwłaszcza strojów bóstw i przedmiotów do nich należących, pojawia się także w mitologicznej literaturze greckiej.

\section{Złoto kolorem bogów greckich}

Mamy przynajmniej kilka oczywistych przykładów ${ }^{41}$. Homer w Iliadzie w następujących słowach opisuje Zeusa ${ }^{42}$, „ojca bogów i ludzi” ${ }^{43}$ :

Tak powiedział i zaprząg konie o nogach spiżowych,

Rącze jak wicher i strojne pozłocistymi grzywami.

Zdaniem Beale’a (The Book, 209) prezentacja Jezusa jako króla i arcykapłana jednocześnie może być zamierzonym zabiegiem autora Apokalipsy, wzorowanym na charakterystyce Szymona „przywódcy i najwyższego kapłana" Izraela (1 Mch 14,35).

39 Forstner, Świat symboliki, 148.

40 Zob. Jelonek, Biblijna teologia, 165.

41 Pierwsze trzy wymienia także Aune (Revelation, 94).

42 Według mitologii greckiej Zeus to największy bóg panteonu helleńskiego. Syn Kronosa i Rei. Jest bogiem światła, pogodnego nieba, jak również piorunu. Panuje na świetlistych wysokościach Nieba, najczęściej zasiada na Olimpie. Utrzymuje na świecie porządek i sprawiedliwość. Koncepcja Zeusa jako potęgi uniwersalnej rozwinęła się od początku poematów homeryckich i doprowadziła greckich filozofów do pojęcia opatrzności: u stoików Zeus jest symbolem jedynego boga uosabiającego Kosmos. W Rzymie utożsamiano Zeusa z Jowiszem. Więcej informacji na temat boga Zeusa zob. Grimal, Stownik mitologii, 361-363. 
Ciało swe także przyodział szatą ze złota, bicz ujął

Również złocisty, roboty pięknej i wstąpił na rydwan ${ }^{44}$.

Podobnie pisze o bracie Zeusa, Posejdonie, władcy mórz ${ }^{45}$ :

Zrobił trzy kroki olbrzymie, za czwartym cel swój osiągnął w Ajgach.

Tam piękne domostwo posiadał w zatoce głębokiej,

Złote, kunsztownej budowy, wieczyście nienaruszone.

Wszedł tam i zaprzagł rumaki o mocnych spiżowych kopytach.

Bystre, z grzywami złotymi, co opływały im szyje.

Szaty nałożył złociste i chwycił biczysko do ręki,

Także ze złota, kunsztownej roboty i skoczył na rydwan ${ }^{46}$.

Jak wynika z powyższych tekstów, schemat literacki przedstawienia Zeusa i Posejdona, którzy zaprzęgają swoje rydwany, literacko jest bardzo podobny ${ }^{47}$ : złote grzywy rumaków, złociste szaty oraz bicz, także złoty, pięknie i kunsztownie wykonany. Wszystkie wymienione elementy wskazują na szczególną ich wartość materialną, ale także na bóstwo ich posiadaczy. W kontekście naszych rozważań na uwagę zasługuje złoty kolor szat Zeusa i Posejdona. W Ap 1,13 barwa szaty Chrystusa zmartwychwstałego nie została jednoznacznie określona. Jedyny element symbolizmu chromatycznego to złoty pas, stanowiący część ubioru Jezusa. Jest on kolorem dominującym w ubiorze Zmartwychwstałego i wskazuje na Jego boską godność. Grecki poeta Kallimach z Cyreny ${ }^{48} \mathrm{w}$ Hymnie 2, nazywanym „złotym” ${ }^{49}$, poświęconym Apollonowi ${ }^{50}$, charakteryzuje jego ubiór w następujący sposób:

44 Homer, Iliada 8, 40-44 (Jeżewska, 181).

45 Posejdon, władca mórz, nie tylko kieruje falami, ale może sprowadzać burze, rozbijać nadmorskie skały jednym ciosem swego trójzębu, za jego sprawą wytryskują też źródła, stąd jego potęga rozciąga się także na źródła, strumienie i jeziora. Więcej informacji na temat boga Posejdona zob. Grimal, Słownik mitologii, 299-301.

46 Homer, Iliada 13, 20-24 (Jeżewska, 295).

47 Zob. Aune, Revelation, 94.

48 Kallimach, Kallímachos, urodzony ok. 310 r., zmarł po 245 r. przed Chr., grecki uczony i poeta z Cyreny (Afryka Północna). Jest najwybitniejszym przedstawicielem poezji aleksandryjskiej i głównym teoretykiem jej poetyki. Najważniejsze jego dzieło to Pinakes („Tablice”) w 120 księgach, będące rozbudowanym katalogiem rękopisów Biblioteki Aleksandryjskiej i pierwszą w dziejach kultury naukowo opracowaną historią literatury greckiej. Z wielu dzieł Kallimacha zachowało się w całości ok. 61 epigramatów (głównie w Antologii palatyńskiej), 6 hymnów: do Zeusa, do Apollona, do Artemidy, na Delos, na kąpiel Pallady oraz do Demetry; zob. Narecki, „Kallimach”, 409-410.

49 Trzy „Hymny” (2, 3 i 4) stanowią pewną całość. „Łączy je wszystkie osoba Apollona (2), ważnego ich bohatera: brata, z którym Artemida współzawodniczy $(3,7)$, oraz syna Leto, dwukrotnie głoszącego wyrocznie z łona matki (4,86-99, 162-195), a w zakończeniu hymnu 4. rodzącego się na Delos, wyspie-piastunce. Jedność Apollona, Artemidy i Delos podkreśla opis ich postaci, których dominującą cechą jest kolor złoty (2,32-34; 3,110-112; 4,260-264). Te „złote” hymny tworzą środek zbioru, uwidaczniając główną rolę Apollona w całej kolekcji” (Żybert-Pruchnicka, „Literacko-religijne”, 93).

50 Apollon był synem Zeusa i Latony, bratem Artemidy. Przedstawiano go jako boga bardzo pięknego, wysokiego, wyróżniającego się zwłaszcza dzięki długim czarnym lokom o błękitnym odcieniu. Był bogiem świa- 
Złoty jest strój Apollona, złocisty płaszcz ma na sobie,

złota lira i łuk liktyjski, złoty też kołczan,

złote nawet sandały, bo szczerozłoty Apollon,

także i przebogaty, a Python tego świadectwem ${ }^{51}$.

Kiedy Latona porodziła Apollona na wyspie Delos ${ }^{52}$, gdzie znalazła schronienie przed gniewem Hery, cała wyspa pokryła się złotem. Tak o tym pisze Kallimach:

Złotem ci wówczas wszystko pokryło, wyspo Delos:

złotem okrągłe jezioro przez dzień cały płynęło,

złotem pędy oliwki narodziny wieńczyły,

złota pełen był nawet głęboki, kręty Inopos.

Ty zaś ze złotej ziemi podniosłaś w górę niemowlę ${ }^{53}$.

Natomiast mały Apollon otrzymał od swego ojca Zeusa cenne dary: złotą mitrę, lirę i rydwan zaprzężony w łabędzie $e^{54}$. Można więc powiedzieć, że złoto w szczególny sposób było symbolem właśnie Apollona: złoty strój, płaszcz, lira, łuk ${ }^{55}$, kołczan, sandały. To pozwala stwierdzić Kallimachowi, że Apollon jest „szczerozłoty”

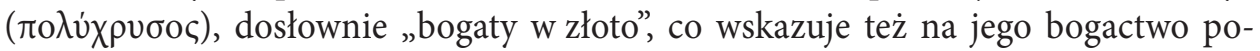
świadczone przez Pythona ${ }^{56}$ (Pytona), mitologicznego smoka (węża) zabitego przez Apollona. W ten sposób zwycięski bóg wzniósł swoją wyrocznię u stóp Parnasu i przejął kontrolę nad legendarnymi bogactwami zgromadzonymi przy wyroczni Gai w Delfach ${ }^{57}$. Wydaje się oczywiste, dlaczego złoto było łączone właśnie zwłaszcza z Apollonem. Ma ono jasną barwę, którego nie niszczy ani śniedź, ani rdza, i w naturalny sposób jest kojarzone z boskością, a szczególnie z bogiem utożsamianym ze słońcem i jego jasnym światłem ${ }^{58}$. W ten sposób mamy swoistego rodzaju portret lśniącego złotem bóstwa.

tła, sprawiedliwości, ładu, prawa i pokoju, patronem sztuki i opiekunem muz, bogiem przepowiedni i wyroczni w Delfach i na Delos. Więcej informacji na temat Apollona zob. Grimal, Słownik mitologii, 34-36. Kallimach, Hymn 2, 32-35 (Biblioteka Antyczna 49, 127).

52 Delos, leżące między Azją a Europą, wśród wysp tworzących „most” między tymi kontynentami, pierwotnie poświęcone było głównie Artemidzie, a później słynęło z kultu Apollona.

53 Kallimach, Hymn 4, 260-265 (Biblioteka Antyczna 49, 173).

54 Zob. Grimal, Stownik mitologii, 34.

55 Grecy przypisywali Apollinowi wraz z jego bliźniaczą siostrą Artemidą wynalezienie łuku i łucznictwa, za sprawą czego do jego atrybutów należał złoty łuk i kołczan srebrnych strzał.

56 Być może jest to epicka nazwa Delf.

57 Zob. Grimal, Słownik mitologii, 308-309.

58 Warto także zauważyć, że postać Apollona, z którym orfizm utożsamiał Heliosa - boga słońca, była także wykorzystywana do przedstawienia Jezusa - Słońca Sprawiedliwości. Wymownym przykładem jest mozaika zachowana na sklepieniu mauzoleum Giulli (Juliuszy) w Grotach Watykańskich pod Bazyliką św. Piotra w Rzymie. Widzimy tam Chrystusa „wyglądającego jak Apollo”. Jest On na rydwanie ciągniętym przez białe konie. Ma rysy pięknego młodego mężczyzny, którego głowę otaczają złote promienie, co 
W opisach bóstw mitologicznych mamy także wyraźnie wspomniany złoty pas $(\zeta \omega \dot{\vee \eta}) . \mathrm{W}$ Hymnie 3 Kallimacha czytamy:

O Artemido dziewicza, coś Tityosa zabiła,

złotą masz broń i przepaskę, na złotym wozie zasiadasz,

złote masz lejce, bogini, którymi kiełznasz jelenie ${ }^{59}$.

Wśród złotego ekwipunku bogini - obok broni, wozu, lejc - Artemida posiada także „złotą przepaskę”. Podobnie Kirke ${ }^{60}$, córka Heliosa, boga Słońca, „sama włożyła wielki srebrzysty faros, lekki i cudny, biodra przepasała pięknym złotym pasem ( $(\omega \dot{\omega} \vee \eta \ldots \chi \rho v \sigma \varepsilon i \eta \eta v)$, na głowę zarzuciła namiotkę" ${ }^{\prime 1}$. Według innego przekładu „spięła kibić gładką złotym pasem misternej złotniczej roboty” ${ }^{2}$. Ciekawe, że oba złote pasy zdobią boginie. Być może sposób przepasania Jezusa „na piersiach”, o czym była wcześniej mowa, mógłby być aluzją do tych figur kobiecych z mitologii greckiej. W każdym razie nie ulega wątpliwości, że także tutaj wszechobecny kolor złoty, zwłaszcza w opisie Artemidy, wskazuje na bóstwo. Potwierdzają to także jeszcze inne złote przedmioty, które były własnością greckich bogów: złocisty kosz (kołyska) Zeusa ${ }^{63}$, łanie Artemidy ze złotymi rogami ${ }^{64}$, złoty tron ${ }^{65}$ oraz złote jabł$\mathrm{ka}^{66}$ Hery, złocisty grzebień ${ }^{67}$ i złoty hełm ${ }^{68}$ Ateny ${ }^{69}$. Można zatem przyjąć, że barwa złota w naturalny niemal sposób symbolicznie odsyła do sfery boskiej, jest bowiem „kolorem bogów”.

było charakterystycznym sposobem przedstawiania Apollona - Heliosa. Warto także zauważyć, że w wizji Chrystusa w Ap 1,16 czytamy, że „Jego oblicze jaśniało jak słońce w swej mocy”, co symbolicznie wskazuje na Jego boskość.

59 Kallimach, Hymn 3, 110-112 (Biblioteka Antyczna 49, 144).

60 Na temat czarodziejki Kirke, zob. Grimal, Stownik mitologii, 184-185. Odniesienie to znajdziemy także u Aune, Revelation, 94. Komentator cytuje także Wergiliusza, opisującego Eneasza, który stanął w „świetle i rozbłysnął, z twarzy, z postaci istny bóg!" (Vergilius, Eneida 1, 588-589 [Kubiak, 58]), a jego matka bogini Wenus:

synowi swemu taką piękność

Włosów i łunę młodości szkarłatną

Przywiała, taki oczu blask radosny,

Jak ręka eburn upiększa, jak srebro

Lub marmur z Paros oprawia się w złoto (Vergilius, Eneida 1, 590-594 [Kubiak, 59]).

61 Homer, Odyseja 10, 544-545 (Parandowski, 167).

62 Homer, Odyseja 10 (Siemieński, 1).

63 Kallimach, Hymn 1, 48 (Biblioteka Antyczna 49, 117).

64 Kallimach, Hymn 3, 103 (Biblioteka Antyczna 49, 144).

65 Kallimach, Hymn 4, 228 (Biblioteka Antyczna 49, 172).

66 Kallimach, Hymn 6, 11 (Biblioteka Antyczna 49, 198).

67 Kallimach, Hymn 5, 31 (Biblioteka Antyczna 49, 185).

68 Kallimach, Hymn 5, 43 (Biblioteka Antyczna 49, 186).

69 Atena - córka Zeusa i Metis, bogini - wojowniczka. W Atenach czczona jako bogini Rozumu; zob. Grimal, Stownik mitologii, 47-48. 


\section{Podsumowanie}

Jedną z podstawowych zasad poprawnej interpretacji symbolizmu Apokalipsy jest konieczność uwzględnienia możliwych źródeł jego pochodzenia. W przypadku złotego pasa Jezusa $(1,13)$ w wizji inauguracyjnej Księgi $(1,12-20)$ jest to niewątpliwie najpierw Stary Testament wraz z wszystkimi odniesieniami, w świetle których złoty kolor szarfy Jezusa wskazuje na Niego jako Boga, Króla i Arcykapłana; wpisuje się dobrze w najbliższy kontekst i znajduje swoje potwierdzenie już w początkowym dialogu liturgicznym, kiedy to zgromadzona wspólnota błogosławi Jezusa jako „Wiernego Świadka”. On pierwszy z umarłych narodził się do życia i ma władzę nad królami ziemi. Jest „Miłujący” i przez swoje misterium paschalne uwolnił od grzechów oraz uczynił chrześcijan ludem królewskim i kapłańskim dla Boga (zob. 1,5-6). Jednak ów chromatyczny symbolizm, zwłaszcza odnoszący się do Jezusa jako Boga, może być znacząco wzbogacony, jeśli weźmiemy pod uwagę możliwe paralele z literatury greckiej, a przede wszystkim opisy mitologicznych bóstw: Zeusa, Posejdona, Artemidy, Apollona. Złoto jest ich dominującym kolorem, a wiele elementów stroju, ekwipunku i sprzętów, którymi posługują się greccy bogowie, zostało wykonanych z tego szlachetnego i drogocennego materiału. Można zatem powiedzieć, że kolor złoty i sam kruszec kojarzą się w sposób naturalny z bóstwem.

Trudno jednoznacznie ustalić, o jakiej zależności możemy mówić w tym przypadku: czy o bezpośrednim wpływie, inspiracji, czy tylko o greckim tle tekstu biblijnego, które może okazać się cenne i konieczne dla jego zrozumienia czy pełnego wyjaśnienia. Przecież wiele tekstów biblijnych, zwłaszcza Nowego Testamentu, a więc także Apokalipsa, powstały w kręgach oddziaływania kultury greckiej. To oznacza, że ich autorzy byli bardziej lub mniej świadomie zakorzenieni w myśleniu greckim, znali najpopularniejsze motywy literackie, zwłaszcza te najbardziej rozpowszechnione, będące w obiegu także w potocznym myśleniu ludzi tamtego czasu. W przypadku symbolizmu złotego pasa Jezusa możemy raczej mówić o szeroko rozumianym jego tle greckim. Wydaje się, że zależności wprost intertekstualne między Apokalipsą a literaturą grecką są raczej mało prawdopodobne, choć nie do końca wykluczone, np. złoty pas Artemidy czy Kirke. W każdym razie odniesienia do greckiej literatury (Iliada, Odyseja, Hymny Kallimacha) jednoznacznie potwierdzają, że złoty kolor pasa Zmartwychwstałego symbolicznie wskazuje na Jego transcendencję, co musiało być bardzo czytelne dla ludzi zakorzenionych w kulturze greckiej. Nie ma wątpliwości, że ostatnia księga Nowego Testamentu, choć pozostaje bliska raczej apokaliptycznej literaturze żydowskiej, wykorzystywała rozmaite motywy i obrazy zapożyczone z mitologii oraz symboliki greckiej, traktując je jako cenny materiał literacki. Warto zatem w interpretacji symbolizmu Apokalipsy uwzględniać kulturę grecko-rzymską jako jego możliwe tło, inspirację czy nawet źródło. 


\section{Bibliografia}

Aune, D.E., Revelation 1-5 (Word Biblical Commentary 52A; Nashville: TN 1997).

Beale, G.K., The Book of Revelation (New International Greek Testament Commentary; Grand Rapids, MI: Eerdmans 1999).

Biguzzi, G., „I numeri nell’Apocalisse di Giovanni e il loro linguaggio”, Liber Annuus 50 (2000) 143-166. Biguzzi, G., Apocalisse (I Libri Biblici. Nuovo Testamento; Milano: Paoline 2005).

Corsini, E., „I numeri nell'Apocalisse”, Apokalypsis. Percorsi nell'Apocalisse in onore di Ugo Vanni (red. E. Bosetti - A. Colacrai) (Assisi: Cittadella 2005) 391-416.

Corsini, E., Apocalisse prima e dopo (Torino: Società Editrice Internazionale 1980).

Díez Merino, L., „La numerología en el Apocalipsis: un principio de hermenéutica”, Ciencia Tomista 127 (2000) 59-98.

Forstner, D., Świat symboliki chrześcijańskiej (Warszawa: PAX 1990).

Gądecki, S., Wstęp do pism Janowych, wyd. 2 (Gniezno: Gaudentinum 1996).

Grimal, P., Słownik mitologii greckiej i rzymskiej (Wrocław: Ossolineum 1987).

Homer, Iliada, wyd. 2 (tł. K. Jeżewska) (Biblioteka Narodowa. Seria II, 17; Wrocław: Ossolineum 1987).

Homer, Odyseja (tł. L. Siemieński) (Gdańsk: Tower Press 2000).

Homer, Odyseja, wyd. 4 (tł. J. Parandowski) (Warszawa: Czytelnik 1967).

Jankowski, A., Apokalipsa św. Jana. Wstęp - przekład z oryginału - komentarz (Pismo Święte Nowego Testamentu 12; Poznań: Pallottinum 1959).

Jelonek, T., Biblijna teologia kapłaństwa (Kraków: WAM 2006).

Józef Flawiusz, Dawne dzieje Izraela (tł. Z. Kubiak - J. Radożycki) (Warszawa: Oficyna Wydawnicza Rytm 1997) I.

Kallimach, Dzieła poetyckie. I. Hymny i epigramy (tł. J. Ławińska-Tyszkowska - A. Kotlińska-Toma) (Biblioteka Antyczna 49; Wrocław: Instytut Studiów Klasycznych, Śródziemnomorskich i Orientalnych Uniwersytetu Wrocławskiego 2016).

Karczewski, M., Reinterpretacja Księgi Rodzaju w Apokalipsie św. Jana (Biblioteka Wydziału Uniwersytetu Warmińsko-Mazurskiego w Olsztynie 55; Olsztyn: SQL 2010).

Kiejza, A., „Charakter obecności Chrystusa w Kościele według Ap 1,12-20”, Collectanea Theologica 65/4 (1995) 21-37.

Kotecki, D., Duch Święty w zgromadzeniu liturgicznym w świetle Apokalipsy św. Jana (Rozprawy i Studia Biblijne 26; Warszawa: Vocatio 2006).

Kotecki, D., Jezus a Bóg Izraela w Apokalipsie św. Jana (Scripta Theologica Thoruniensia 27; Toruń: Wydawnictwo Naukowe UMK 2013).

Kotecki, D., „Kryteria interpretacji Apokalipsy św. Jana”, Biblica et Patristica Thoruniensia 5 (2012) 15-34.

Lijka, K., „Dzień Pański według Apokalipsy”, Liturgia Sacra 3/2 (1997) 33-39.

Manunza, C., L'Apocalisse come "actio liturgica" cristiana. Studio esegetico-teologico di Ap 1,9-16; 3,14-22; 13,9-10; 19,1-8 (Analecta Biblica 199; Roma: Gregorian \& Biblical Press 2012).

Marconi, N., Le mille immagini dell'Apocalisse. Una introduzione al linguaggio audiovisivo dell'Apocalisse (Milano: Paoline 2002).

Mounce, R.H., Apocalisse (Chieti: GBU 2013).

Narecki, K., „Kallimach z Cyreny”, Encyklopedia katolicka (red. B. Migut) (Lublin: Towarzystwo Naukowe KUL 2000) VIII, 409-410. 


\section{PAWEt PODESZWA}

Ostański, P., Objawienie Jezusa Chrystusa. Praktyczny komentarz do Apokalipsy (Ząbki: Apostolicum 2005).

Parchem, M., Księga Daniela (Nowy Komentarz Biblijny. Stary Testament 26; Częstochowa: Edycja Świętego Pawła 2008).

Podeszwa, P., „Chrystus jako Arcykapłan w świetle J 19,23 i Ap 1,13”, Od Melchizedeka do Jezusa Arcykapłana. Biblia o kapłaństwie (red. D. Dziadosz) (Analecta Biblica Lublinensia 5; Lublin: Wydawnictwo KUL 2010) 193-207.

Podeszwa, P., „Pan świeczników i gwiazd» (Ap 1,12-20) G. Bednarskiego - ilustracja czy interpretacja pierwszej wizji Apokalipsy Janowej?", Biblica et Patristica Thoruniensia 11/1 (2018) 57-85.

Podeszwa, P., Paschalna pamięćo Jezusie. Studium egzegetyczno-teologiczne wyrażenia ì $\mu \alpha \rho \tau v \rho i \alpha$

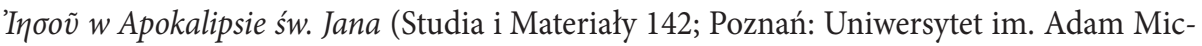
kiewicza 2011).

Popielewski, W., Alleluja! Liturgia godów Baranka eschatologicznym zwycięstwem Boga (Ap 19,1-8) (Studia Biblica 1; Kielce: Verbum 2001).

Prigent, P., L’Apocalypse de Saint Jean (Commentaire du Nouveau Testament. Deuxième série 14; Genève: Labor et Fides 2000).

Ravasi, G., Apokalipsa (Kielce: Jedność 2002).

Rigato, M.-L., Giovanni. L'Enigma il Presbitero il culto il Tempio la cristologia (Testi e commenti; Bologna: Dehoniane 2007).

Rojas Gálvez, I., I simboli dell'Apocalisse (Bologna: Dehoniane 2016).

Romaniuk, K. - Jankowski, A., Kapłaństwo w Piśmie Świętym Nowego Testamentu, wyd. 2 (Kraków: Tyniec Wydawnictwo Benedyktynów 1994).

Stern, D.H., Komentarz żydowski do Nowego Testamentu (Prymasowska Seria Biblijna; Warszawa: Vocatio 2004).

Szamot, M., Apokalipsa czytana dzisiaj (Kraków: WAM 2000).

Vanhoye, A., „L'Apocalisse e la Lettera agli Ebrei”, Apokalypsis. Percorsi nell'Apocalisse in onore di Ugo Vanni (red. E. Bosetti - A. Colacrai) (Assisi: Cittadella 2005) 257-275.

Vanni, U., L'Apocalisse. Ermeneutica, esegesi, teologia (Supplementi Rivista Biblica 17; Bologna: Dehoniane 1991).

Vergilius (Publius Vergilius Maro), Eneida (tł. Z. Kubiak) (Bibliotheca Mundi; Warszawa: Państwowy Instytut Wydawniczy 1987).

Wojciechowski, M., Apokalipsa świętego Jana. Objawienie, a nie tajemnica (Nowy Komentarz Biblijny. Nowy Testament 20; Częstochowa: Edycja Świętego Pawła 2012).

Wojciechowski, M., „Wpływy greckie w Apokalipsie św. Jana”, Biblica et Patristica Thoruniensia 5 (2012) 115-124.

Wojciechowski, M., Wpływy greckie w Biblii (Kraków: WAM 2012).

Zbroja, B., „Symbolika arytmetyczna Apokalipsy”, Inkulturacja Biblii (red. T. Jelonek) (Kraków: Wydawnictwo Naukowe Papieskiej Akademii Teologicznej 2007) 131-158.

Żybert-Pruchnicka, E., „Literacko-religijne poematy Kallimacha”, Kallimach, Dzieła poetyckie. I. Hymny i epigramy (tł. J. Ławińska-Tyszkowska - A. Kotlińska-Toma) (Biblioteka Antyczna 49; Wrocław: Instytut Studiów Klasycznych, Śródziemnomorskich i Orientalnych Uniwersytetu Wrocławskiego 2016) 69-104. 